\section{Persisting antibodies to glutamic acid decarboxylase in Type 1 (insulin-dependent) diabetes mellitus are not associated with neuropathy}

Dear Sir,

Islet cell antibodies (ICA b) become undemonstrable by immunofluorescence in most cases within a few years after the diagnosis of Type 1 (insulin-dependent) diabetes mellitus. This is explained by the loss of an antigenic reservoir as the islet beta cells are completely destroyed [1]. Autoantibodies to glutamic acid decarboxylase (GAD), previously known as the $64 \mathrm{kDa}$ autoantigen $[2,3]$, earlier appeared to fade in a similar way. Thus, Kaufman et al. [4] reported that levels and frequency of anti-GAD decreased markedly during the first years after detection, and when these did persist, an explanation invoked was diabetic neuropathy which could allow GAD to leak from the demaged peripheral nerves and sustain or reactivate the antibody response. Our experience is inconsistent with this idea.

We find that the decrease in frequency of positivity for anti-GAD in Type 1 diabetic patients is not nearly as great as for ICA b. Among the sera studied during 1991-1992, anti-GAD was positive for 147 of $207(71 \%)$ cases of Type 1 diabetes with a duration $0-5$ years, 50 of $85(59 \%)$ cases with a duration $6-10$ years, and 48 of $89(54 \%)$ cases with duration over 10 years.

Furthermore, we studied 32 diabetic patients with severe polyneuropathy which had been verified by nerve conduction studies. These were 18 with Type 1 diabetes, ten female and eight male, with a mean age of $52 \pm 11$ years, a mean age at onset of diabetes of $30 \pm 13$ years, and a disease duration of $22 \pm 7$ years; and 14 with Type 2 diabetes, four female and ten male, with a mean age of $61 \pm 8$ years, a mean age at onset of $48 \pm 9$ years, and a disease duration of $13 \pm 8$ years. Anti-GAD was tested for by a radioimmunoprecipitation assay [5]. Of the Type 1 diabetic patients, 10 of 18 were positive for anti-GAD (56\%), a frequency similar to that found for all Type 1 diabetic patients of more than 10 years duration irrespective of the presence or not of clinically evident neuropathy. None of the 14 patients with Type 2 diabetes and clinically evident neuropathy were positive. In addition, we tested sera from 42 patients with leprosy, 23 female and 19 male, which, in the tuberculoid and intermediate forms, is often accompanied by peripheral neuropathy and antibodies to constituents of both nerves and skin [6]. In this group, 28 had polar lepromatous leprosy, 10 had intermediate lepromatous-tuberculoid leprosy, and 4 had polar tuberculous leprosy.
Only one serum, from a patient with polar lepromatous leprosy, was positive for anti-GAD, and this weakly so (48 units; upper normal limit, defined as mean $+3 \mathrm{SD}$ of blood donor sera, is 20 units).

In conclusion, we can infer that in Type 1 diabetes levels of antiGAD persist for long periods unlike ICA $b$, and this persistence is not explained by diabetic neuropathy. Also, the existence of neuropathy of itself, and in the absence of the genetic-environmental background particular to Type 1 diabetes, is not associated with an anti-GAD response.

Yours sincerely,

T.Tuomi, P.Z.Zimmet, M.J.Rowley, S.W.Serjeantson, and I. R. Mackay

\section{References}

1. Hagopian W, Lernmark A (1992) Autoimmune diabetes mellitus. In: Rose NE, Mackay IR (eds) The autoimmune diseases II. Academic Press Inc. New York, pp 235-278

2. Baekkeskov S, Landin M, Kristensen JK et al. (1987) Antibodies to $a 4,000 \mathrm{M}_{\mathrm{r}}$ human islet cell antigen precede the clinical onset of insulin-dependent diabetes. J Clin Invest 79: 926-934

3. Baekkeskov S, Aanstoot H, Christgau S et al. (1990) Identification of the $64 \mathrm{~K}$ autoantigen in insulin-dependent diabetes as the GABA-synthesizing enzyme glutamic acid decarboxylase. Nature 347: 151-156

4. Kaufman DL, Erlander MG, Clare-Salzler M, Atkinson MA, Maclaren NK, Tobin AJ (1992) Autoimmunity to two forms of glutamate decarboxylase in insulin-dependent diabetes mellitus. J Clin Invest 89:283-292

5. Rowley MJ, Mackay IR, Chen Q, Knowles WJ, Zimmet PZ (1992) Antibodies to glutamic acid decarboxylase discriminate major types of diabetes mellitus. Diabetes 41: 548-561

6. Ehrenstein M, Isenberg D (1991) Autoimmunity associated with infection: leprosy, acute rheumatic fever and Lyme disease. Curr Opin Immunol 3: 930-935

Dr. T. Tuomi

Centre for Molecular Biology and Medicine

Monash University

Clayton 3168

Victoria

Australia

\title{
Erratum
}

Diabetologia, Volume 36, Number 5, May 1993

p 473 C.D.A. Stehouwer: Response from the authors

On page 473 (right-hand column, line 13) the correct text should read: “... Finally, from the data presented by Dr. Vermes, it appears premature to conclude that plasma endothelin levels correlate with urinary albumin excretion. Endothelin levels may be influenced by gender [2], atherosclerosis and renal function; ...". 